\title{
Estimation of Methane Emissions from Mirash Municipal Solid Waste Sanitary Landfill, Differences between IPPC 2006 and LandGEM Method
}

\author{
Biserka Dimishkovska'; Afrim Berisha²*; Kiril Lisichkov³ \\ 1 Ss. Cyril and Methodius University, Institute of Earthquake Engineering and Engineering Seismology, IZIIS, \\ Todor Aleksandov Str. no. 165, 1000, Skopje, Republic of Macedonia \\ 2 Kosovo Environmental Protection Agency, Rilindja Building XV/04, Str. Luan Haredinaj, 1000 Prishtina, \\ Republic of Kosovo \\ 3 Ss. Cyril and Methodius University, Faculty of Technology and Metallurgy, Rugjer Boshkovic Str. no. 16, \\ 1000 Skopje, Republic of Macedonia \\ * Corresponding author's e-mail: afrimberisha2010@gmail.com
}

\begin{abstract}
This paper deals with the estimation of methane emissions from the Mirash municipal solid waste sanitary landfill. The methane emission was calculated according to two different methodologies, namely, IPCC 2006 and LandGEM. Within the framework of the research, the following parameters were evaluated: the amount of landfilled waste, landfill characteristics, and composition of landfilled waste as well as the climate conditions prevailing in the region. According to the IPCC methodology, the total amount of methane emitted from the Mirash landfill during the period 2006-2017 was 30.57 Giga grams (Gg), while according to the LandGEM methodology, the total amount of methane emitted from the Mirash landfill in the period 2006-2017 was 26.32 Giga grams (Gg). The total mass of $\mathrm{CH}_{4}$ in the Mirash regional landfill for the years 2018-2025 is projected to be $53.74 \mathrm{Gg}$ according to the IPCC method, while according to LandGEM method, the projection points to $50.74 \mathrm{Gg}$. This study was carried out for the sanitary landfill for solid waste management in Mirash, Prishtina Region, in the Republic of Kosovo, during the year of 2018.
\end{abstract}

Keywords: emissions, methane, municipal solid waste (MSW), sanitary landfill, Mirash.

\section{INTRODUCTION}

Urbanization and changes in the life style of the urban population have given rise to the generation of solid waste (Darban Astane, et. al., 2017). Municipal waste generation in Kosovo increases, following the GDP growth and is similar to that in other Western Balkan countries. Waste generation has nearly followed the region's upward trend in GDP, which is attributed to the constant economic growth accompanying liberal markets and return of stability (ZOI Net, 2012). This trend is different from that in the EU member countries where the municipal waste generation is decreased. In total, $60 \%$ of the Kosovo population use the refuse collection service. In Kosovo, there is no developed infrastructure for collection, landfilling and separation of municipal waste all over the country's territory. This has resulted in a high number of illegal landfills. In addition, there is the problem of dumps, especially in the rural areas where there is no waste collection system organized by the competent authorities (Milenkovic, et al., 2017; Morina, et al., 2017). Before 2000, most of the solid waste collected from the urban areas in Kosovo was deposited in unmanaged landfills or waste dump sites. During the past decade (2006-2016), there was an improvement of waste disposal infrastructure from open dumping and unmanaged landfills to managed sanitary landfills. Such improvement of waste management increased the amount of disposed waste. At 
present, about $60 \%$ of the solid waste is disposed of in sanitary landfills (Veselaj, et al., 2014). One of the major impacts of waste disposal in sanitary landfills or illegal dump sites is the emission of greenhouse gases, mainly methane, to the atmosphere (Berisha, et al., 2018). These greenhouse gases are produced from the biodegradation of waste under anaerobic conditions through microbial activities. These waste disposal sites are considered as one of the most common anthropogenic sources of greenhouse gases (Scheutz, et al., 2009; Powell, et al., 2015). The methane gas emitted from the waste disposal sites has a global warming potential that is 25 times greater than that of carbon dioxide (IPCC, 2006). The bio-degradation of these deposited wastes leads to the production of landfill gases with a high risk of explosion (Huseyin, et al., 2018). The emissions of greenhouse gases (GHG)from the managed waste in Kosovo represent around 3-4\% of the total national GHG emissions. The methane emissions from the sanitary municipal solid waste landfills are the major source of GHG emissions from the waste sector in Kosovo (Berisha, et al., 2015; KEPA, 2015; UNDP Kosovo, 2012). There are 6 municipal and regional waste landfills in the territory of Kosovo that are considered as potential hotspots. These landfills bear a potential risk regarding the impact on air, water, soil and public health (Veselaj, et al., 2013). The largest sanitary landfill for solid waste management in Kosovo is Mirash, located in the Prishtina region, in the Republic of Kosovo.

\section{MATERIAL AND METHODS}

\section{Study area}

The observed landfill represents a sanitary landfill for solid waste management in the Prishtina region, situated in the Mirash location (Fig. 1). This landfill serves for depositing of waste collected from the following municipalities: Prishtina, Gracanica, Obiliq, Lipjan, Fushe Kosove, and Gllogovc. The information presented in table 1 shows that the population covered by the refuse collection service in the region represents $61.2 \%$ (or 238.810 inhabitants) of the population of the region (MLGA, 2017).

The landfill was established in 2006. An excavated coal mine with bordering walls was prepared and coated with a polyethylene foil sealing layer. The waste landfilling process in the sanitary solid waste landfill started in 2006 . The total surface of the landfill is about 40 ha. The waste landfilling area has a size of about 8 ha. The waste landfilling is to continue until the year of 2025. At present, the average waste layer height is about $13 \mathrm{~m}$ (KEPA, 2015; GIZ, 2015). In the Mirash landfill, a number of passive degassing wells are installed in different zones of the covered and non-covered landfill body. There is no adequate equipment for active degassing of the landfill (table 2).

Mirash landfill is located in the Prishtina region, which is characterized by a prevailing continental climate with $640 \mathrm{~mm} / \mathrm{yr}$ of rainfalls and

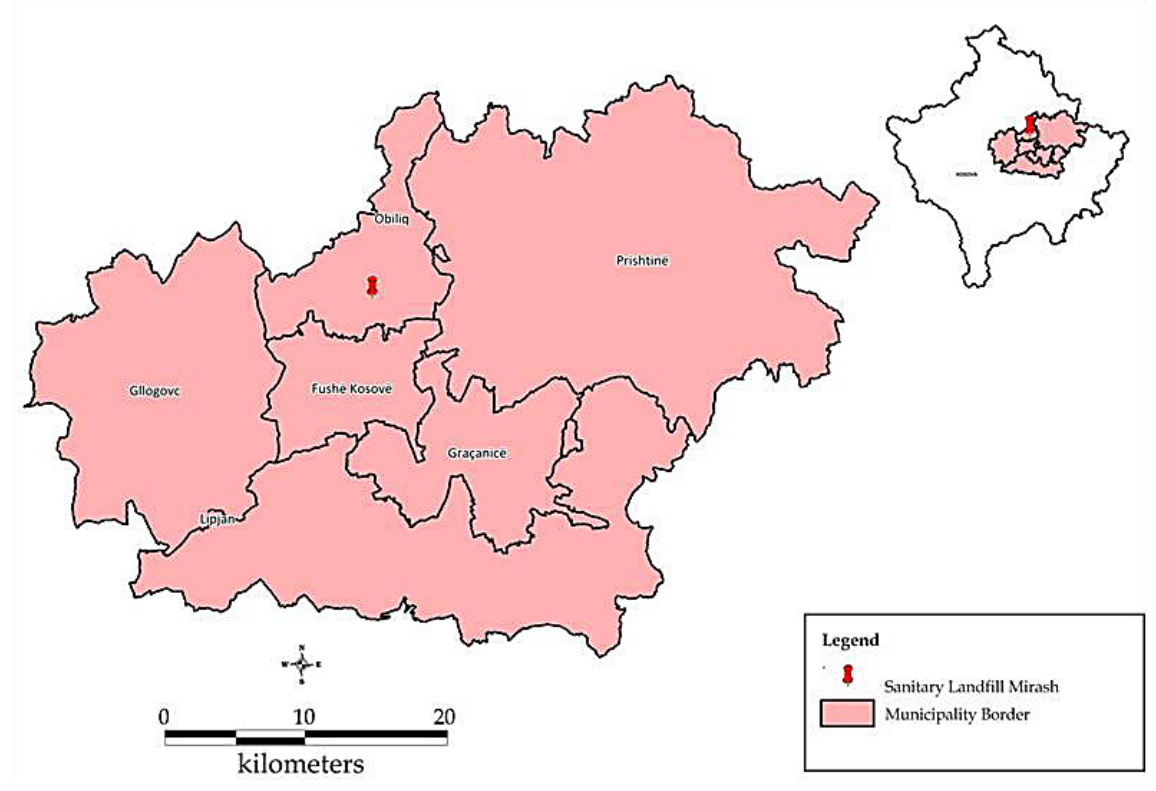

Fig. 1. Geographic location of the studied area 
Table 1. Population covered by the refuse collection service in the Prishtina region

\begin{tabular}{|l|l|c|c|c|c|}
\hline $\begin{array}{c}\text { Name of the regional } \\
\text { sanitary landfill }\end{array}$ & Municipalities & $\begin{array}{c}\text { Area covered by } \\
\text { the municipality } \\
\mathrm{km}^{2}\end{array}$ & $\begin{array}{c}\text { Nr. of } \\
\text { population }\end{array}$ & $\begin{array}{c}\text { \% of population } \\
\text { covered by the refuse } \\
\text { collection service }\end{array}$ & $\begin{array}{c}\text { Nr. of population } \\
\text { covered by the refuse } \\
\text { collection service }\end{array}$ \\
\hline \multirow{4}{*}{$\begin{array}{l}\text { Sanitary landfill in } \\
\text { Mirash }\end{array}$} & Prishtina & 523 & 204721 & $65 \%$ & 133069 \\
\cline { 2 - 6 } & Gllogovc & 276 & 60175 & $56 \%$ & 33898 \\
\cline { 2 - 6 } & Obiliq & 105 & 19165 & $70 \%$ & 13416 \\
\cline { 2 - 6 } & Fushe Kosovo & 84 & 37048 & $97 \%$ & 35936 \\
\cline { 2 - 6 } & Lipjan & 338 & 56643 & $25 \%$ & 14161 \\
\cline { 2 - 6 } & Gracanica & 122 & 11900 & $70 \%$ & 8330 \\
\hline Total & 1448 & 389652 & $61.2 \%$ & 238810 \\
\hline
\end{tabular}

Table 2. Characteristics of the Mirash sanitary landfill

\begin{tabular}{|c|c|c|c|c|c|c|c|}
\hline $\begin{array}{l}\text { Starting year } \\
\text { of operation }\end{array}$ & $\begin{array}{l}\text { Type of a } \\
\text { landfill }\end{array}$ & $\begin{array}{l}\text { Landfill } \\
\text { status }\end{array}$ & Landfill area & $\begin{array}{c}\text { Waste } \\
\text { deposition } \\
\text { area }\end{array}$ & $\begin{array}{l}\text { Maximal } \\
\text { height of } \\
\text { waste }\end{array}$ & $\begin{array}{c}\text { Total } \\
\text { deposited } \\
\text { waste in tons } \\
\text { until } 2016\end{array}$ & $\begin{array}{c}\text { Waste deposition is } \\
\text { planned up to the } \\
\text { year }\end{array}$ \\
\hline 2006 & $\begin{array}{c}\text { Managed } \\
\text { semi-aerobic }\end{array}$ & $\begin{array}{c}\text { Currently in } \\
\text { use }\end{array}$ & 40 ha & 8 ha & $13 \mathrm{~m}$ & 985,207 & 2025 \\
\hline
\end{tabular}

with an average yearly air temperature of about $11.4^{\circ}$ Celsius (KHMI, 2017). Figure 2 shows the climate conditions in the Prishtina Region for the years 2006-2017.

The yearly amount of deposited waste in the sanitary landfill in Mirash amounted to about 121.785 tons in 2017. Cumulatively, about 1.106.992 tons of waste was deposited in the period 2006-2017 (Berisha, et al., 2015; KAS, 2017). More detailed information is presented in Table 3.

The composition of fractions of the municipal solid waste is one of the main parameters that affect the GHG emission from the landfill (Sandhya, et al., 2011). According to the analysis of the waste composition performed for the Prishtina region, it is characterized by a higher content of organic waste fractions. The main fractions of waste composition are food waste accounting for $36 \%$ while paper and cardboard account for $13 \%$ (Veselaj, et al., 2014; MESP, 2017). The solid waste composition in the Prishtina region is presented in Figure 3.

\section{Quantification of $\mathrm{CH}_{4}$ emission}

The calculation of $\mathrm{CH}_{4}$ emission from the landfill in Mirash was based on the data on the landfilled waste for the period 2006-2017. In order to perform emission calculations over the years 2006-2017, annual data on waste disposal and data on the fractions of waste deposited into the sanitary landfills were collected from the Kosovo Environmental Protection Agency and the Statistical Agency of Kosovo and then entered

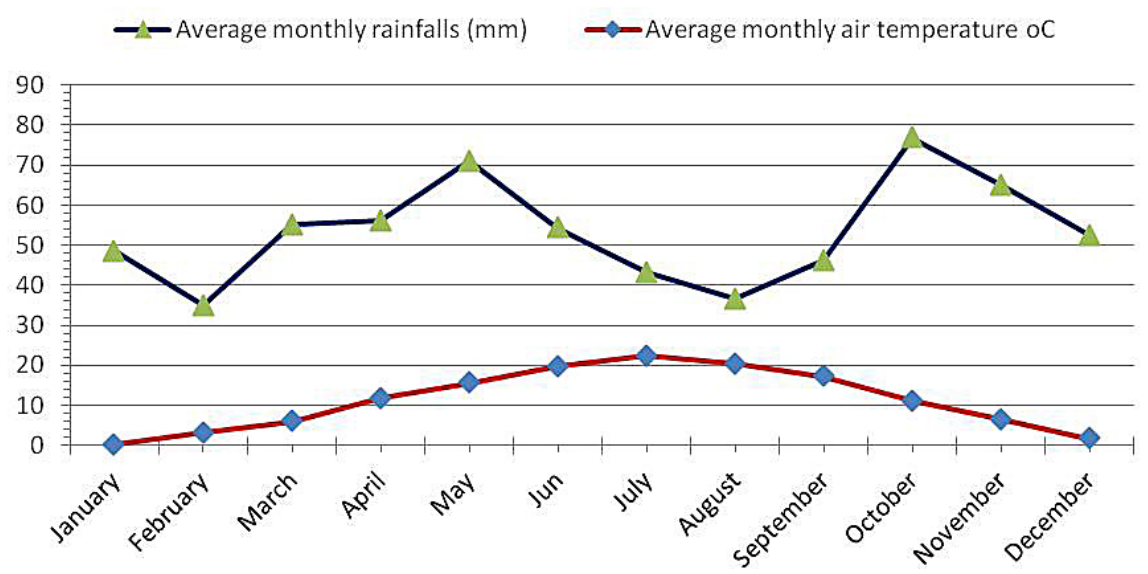

Fig. 2. Climate conditions in the Prishtina region in the period 2006-2017 (KHMI, 2017) 
into the IPCC 2006 model spreadsheet as well as the Landfill Gas Emission Model (LandGEM), an automated estimation tool.

Method 1 IPCC 2006: The calculations of the $\mathrm{CH}_{4}$ emission from the landfill were performed in Microsoft Excel 2007 spreadsheets according to the IPCC guidelines (IPCC, 2006). The IPCC default method for estimation of methane emission from waste disposal sites is based on the following equation:

$$
\begin{gathered}
\text { Methane emissions }= \\
\left(\mathrm{MSWT}^{*} \mathrm{MSWF} \mathrm{MCF}^{*} \mathrm{DOC} * \mathrm{DOCF}\right. \\
\left.* \mathrm{~F}^{*} 16 / 12-\mathrm{R}\right) *(1-\mathrm{OX})
\end{gathered}
$$

where: $M S W T=$ Total amount of generated waste (Gg/year)

$M S W F=$ Fraction of disposed waste

$M C F=$ Correction factor of the waste fraction that generates methane gas from the sanitary landfill

$D O C=$ Fraction of biodegradable organic carbon

DOCF $=$ Fraction of biodegradable organic carbon that is readily available for degradation

$F=$ Fraction of methane in biogas

$O X=$ Fraction of methane gas that is oxidized into carbon dioxide

$R=$ Recovered $\mathrm{CH}_{4}(\mathrm{Gg} / \mathrm{yr})$

The specific parameters and values applied for estimation of the $\mathrm{CH}_{4}$ emissions from the Mirash landfills according to the IPCC method are presented in Table 4.

Method 2 LandGEM: The Landfill Gas Emission Model (LandGEM) is an automated estimation tool with a Microsoft Excel interface that can be used to estimate the emission rates for all
Table 3. Waste disposal in the Mirash sanitary landfill 2006-2017 (Berisha, et al., 2015; KSA, 2017).

\begin{tabular}{|c|c|c|c|}
\hline No. & Year & $\begin{array}{c}\text { Waste disposal } \\
\text { per year/tons }\end{array}$ & $\begin{array}{c}\text { Accumulated disposed } \\
\text { waste (tons) }\end{array}$ \\
\hline 1. & 2006 & 77.000 & 77.000 \\
\hline 2. & 2007 & 77.250 & 154.250 \\
\hline 3. & 2008 & 79.568 & 233.818 \\
\hline 4. & 2009 & 81.955 & 315.773 \\
\hline 5. & 2010 & 84.413 & 400.186 \\
\hline 6. & 2011 & 86.946 & 487.132 \\
\hline 7. & 2012 & 89.554 & 576.686 \\
\hline 8. & 2013 & 92.241 & 668.927 \\
\hline 9. & 2014 & 95.008 & 763.935 \\
\hline 10. & 2015 & 104.743 & 868.678 \\
\hline 11. & 2016 & 116.529 & 985.207 \\
\hline 12. & 2017 & 121.785 & 1.106 .992 \\
\hline
\end{tabular}

landfill gases including methane. LandGEM can use either site-specific data or default parameters to estimate emissions if no site-specific data are available (Alexander, et al., 2005; Kumar et al., 2014). LandGEM is one of the most commonly used and most flexible models (Sadeghi, et al., 2015). The model is presented to estimate annual emissions over a time period based on user specification (Kalantarifard, et al., 2012; Rodrigue, et al., 2018). The model contains two sets of default parameters, CAA defaults and inventory defaults. The CAA defaults are based on the USA federal regulations for MSW landfills laid out by the Clean Air Act (CAA). The inventory defaults are based on the emission factors in EPA's Compilation of Air Pollutant Emission Factors (AP-42). LandGEM uses the following first-order decomposition rate equation to estimate annual emissions over a specified time period.

\section{Waste Composition \%}

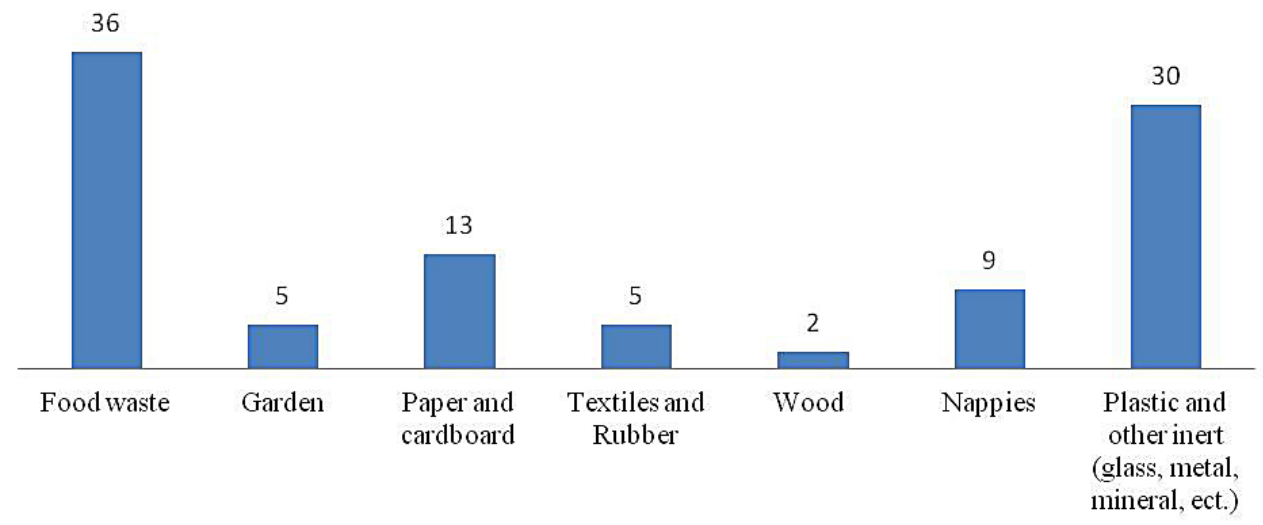

Fig. 3. Waste composition in the Prishtina region (mass \%) (Veselaj, et al., 2014; MESP, 2017) 
Table 4. Parameters used for the sanitary landfills according to the IPCC 2006 default value (IPCC, 2006)

\begin{tabular}{|c|c|c|}
\hline \multicolumn{2}{|c|}{ Parameters } & \multirow{2}{*}{$\frac{\text { Value }}{0.15}$} \\
\hline \multirow{6}{*}{$\begin{array}{l}\text { DOC (Degradable organic carbon) } \\
\text { (weight fraction, wet basis) } \\
\text { Waste by composition }\end{array}$} & Food waste & \\
\hline & Garden & 0.2 \\
\hline & Paper & 0.4 \\
\hline & Wood and straw & 0.43 \\
\hline & Textiles & 0.24 \\
\hline & Disposable nappies & 0.24 \\
\hline \multicolumn{2}{|l|}{ DOCf (fraction of DOC dissimilated) } & 0.5 \\
\hline \multirow{6}{*}{$\begin{array}{l}\text { Methane generation rate constant }(\mathrm{k}) \\
\left(\text { years }^{-1}\right)\end{array}$} & Food waste & 0.185 \\
\hline & Garden & 0.1 \\
\hline & Paper & 0.06 \\
\hline & Wood and straw & 0.03 \\
\hline & Textiles & 0.06 \\
\hline & Disposable nappies & 0.1 \\
\hline \multicolumn{2}{|l|}{ Delay time (months) } & 6 \\
\hline \multicolumn{2}{|l|}{ Fraction of methane $(F)$ in developed gas } & 0.5 \\
\hline \multicolumn{2}{|l|}{ Conversion factor, $\mathrm{C}$ to $\mathrm{CH}_{4}$} & 1.33 \\
\hline \multicolumn{2}{|l|}{ Oxidation factor (OX) } & 0 \\
\hline \multicolumn{2}{|c|}{ Methane Correction Factor (MCF) for managed semi-anaerobic landfills } & 0.5 \\
\hline
\end{tabular}

Table 5. LandGem inventory default values used for the calculation (Alexander, et al., 2005).

\begin{tabular}{|l|c|}
\hline Methane Generation Rate, k (year $\left.{ }^{1}\right)$ & 0.05 \\
\hline $\begin{array}{l}\text { Potential Methane Generation Capacity, } \\
\mathrm{L}_{\mathrm{o}}\left(\mathrm{m}^{3} / \mathrm{Mg}\right)\end{array}$ & 170 \\
\hline Methane Content (\% by volume) & 50 \\
\hline
\end{tabular}

$Q_{C H_{4}}=\sum_{i=1}^{n} \sum_{j=0.1}^{10} k L_{0}\left(\frac{M_{i}}{10}\right)\left(e^{-k t} i, j\right)$

where: $Q C H 4=$ annual methane generation in the year of the calculation $\left(\mathrm{m}^{3} /\right.$ year $)$

$i=1$ year time increment $\mathrm{n}=$ (year of the calculation) - (initial year of waste acceptance)

$j=0.1$ year time increment

$k=$ methane generation rate (year-1)

$L o=$ potential methane generation capacity $\left(\mathrm{m}^{3} / \mathrm{Mg}\right)$

$M i=$ mass of waste accepted in the ith year $(\mathrm{Mg})$

tij = age of the jth section of waste mass $\mathrm{Mi}$ accepted in the ith year (decimal years, e.g., 3.2 years)

Used in this research were the inventory CAA default values for landfills presented in Table 3 .

\section{RESULTS AND DISCUSSION}

The calculations of the $\mathrm{CH}_{4}$ emissions from waste landfilled in the Mirash sanitary landfill in the period 2006-2016 are presented in Table 6, showing that the total mass of $\mathrm{CH}_{4}$ generated in the Mirash landfill during 2006-2017 amounted to $30.57 \mathrm{Gg}$ according to the IPCC method and $26.32 \mathrm{Gg}$ according to the LandGEM method.

The calculations of the projections of $\mathrm{CH}_{4}$ emissions from the landfilled waste for the years 2018-2025 in Mirash sanitary landfill are presented in Figure 4. The total mass of $\mathrm{CH}_{4}$ from the Mirash sanitary landfill for the time period 2017-2025 was projected to 53.74 Gg according to the IPCC method, while the total mass of $\mathrm{CH}_{4}$ projected according to the LandGEM method was $50.74 \mathrm{Gg}$.

As $\mathrm{CH}_{4}$ is produced by bacterial decomposition of organic fractions within landfills, the amount of organic waste within a landfill dictates the amount of produced gas, whereat higher concentrations of organic matter yield higher concentrations of methane (Kumar, et al., 2004; Mutasem El-Fadel, et al., 2002). Several physical conditions and interactions influence methane emission from landfills. Waste composition, air temperature, topography, pressure, $\mathrm{pH}$ and microbial interactions are some of the factors 
Table 6: Calculated $\mathrm{CH}_{4}$ emissions from the waste deposited in the Mirash sanitary landfills, 2006-2017 (Gg/yr)

\begin{tabular}{|c|c|c|c|c|c|c|c|c|c|c|c|c|c|}
\hline \multirow{3}{*}{$\begin{array}{l}\mathrm{CH}_{4} \\
\text { emissions } \\
\text { (Gg/yr) }\end{array}$} & Year & 2006 & 2007 & 2008 & 2009 & 2010 & 2011 & 2012 & 2013 & 2014 & 2015 & 2016 & 2017 \\
\hline & $\begin{array}{l}\text { IPCC } 2006 \\
\text { method }\end{array}$ & 0 & 0.55 & 1.06 & 1.54 & 1.99 & 2.43 & 2.85 & 3.25 & 3.63 & 3.99 & 4.41 & 4.87 \\
\hline & $\begin{array}{l}\text { LandGEM } \\
\text { Method }\end{array}$ & 0 & 0.42 & 0.83 & 1.23 & 1.63 & 2.01 & 2.40 & 2.78 & 3.16 & 3.53 & 3.94 & 4.39 \\
\hline
\end{tabular}

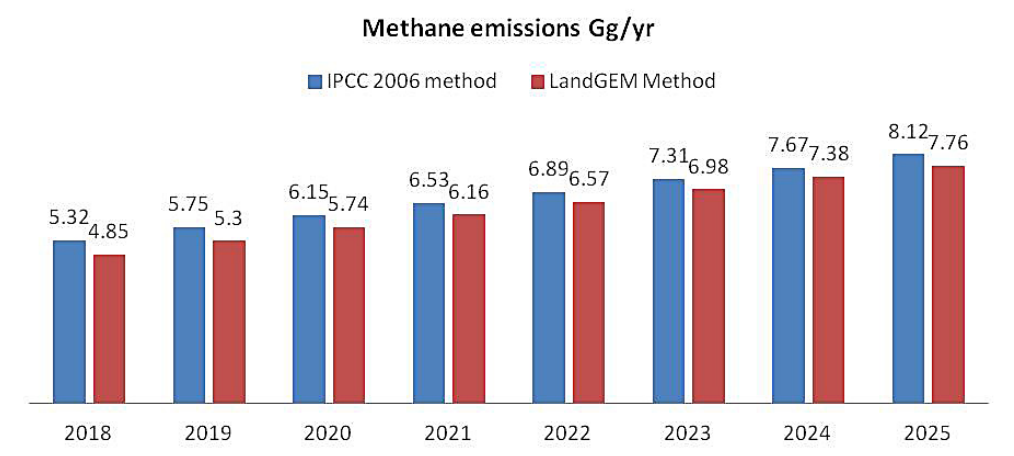

Fig. 4: Projections of $\mathrm{CH}_{4}$ emissions from the Mirash sanitary landfill 2018-2025

considered important for methane generation and emission levels (EPA, 2001; Zawieja, et al., 2011). The ambient temperature and rainfall exhibit strong correlations with landfill gas components (Yang, et al., 2015; Delkash, et al 2015). The landfills without gas collection systems are predisposed to emit substantial amount of $\mathrm{CH}_{4}$ to the atmosphere, with expectation of a large spatial and seasonal variability (Bogner, et al., 2011). The research results show that there is a small difference in the total methane calculated by the two methods used. There is also a progressive increase in the amount of methane emitted from year to year according to both methods. The LandGem method is easier to use since it requires less information to calculate the emissions from sanitary landfills.

\section{CONCLUSIONS}

Methane monitoring and reporting in waste landfilling is of significant importance as landfilling is still the most common waste disposal method worldwide. The calculations of $\mathrm{CH}_{4}$ emissions from the waste landfilled during 2006-2017 in the Mirash sanitary landfill were based on the amount of waste disposal and the use of the IPCC method and the LandGEM method, showing small differences in the total amount of calculated emissions. Additional specific information on the region (waste composition, climate conditions and landfill characteristics) was also considered. The results of the study provide important information which can be used for development of the country specific emission factor for the estimation of the methane emissions in the waste disposal category.

This paper could serve as a source of scientific information for the improvement of decision making on the sustainability waste management projects in Kosovo. The mitigation of the GHG emissions from the sanitary landfill in the Prishtina region is proposed to be addressed in the context of integrated waste management. Implementation of standards that encourage the landfill $\mathrm{CH}_{4}$ recovery and reduction of the quantity of landfilled biodegradable waste is important and will bring environmental and economic benefits. Implementation of control measures and installation of a positive displacement fan ventilation system in the landfill is recommended.

\section{REFERENCES}

1. Alexander, A., Clint Burklin, C., Singleton,. A. 2005. Eastern Research GroupMorrisville, NC US EPA, 2005, Landfill Gas Emissions Model (LandGEM) Version 3.02 User's Guide. 1-56.

2. Berisha, A.; Hajdari, R.; Behrami, S.; Veselaj, T.; Kafexholli, B.; Restelica, S.; Hyseni, M.; Bajraktari, F.; Latifi, L,; Morina, I.; Maxhuni, Mehmeti, M.; Spanca, V.; Pllana, A.; Mahmuti,A.; Mustafa, N.; Raci, S.; Shala, A.; Shala, Sh., 2015. State of the Environment 2015, Kosovo Environmental 
Protection Agency 1-121.

3. Berisha, A., Veselaj, T., Shallaku, F. 2018. Estimation of methane emission from solid waste landfill in Prizren. Albanian J. Agric. Sci. (Special edition 2018) 471- 476.

4. Bogner, J.E.; Spokas, K.A.; Chanton, J.P., 2017. Seasonal Greenhouse Gas Emissions (Methane, Carbon Dioxide, Nitrous Oxide) from Engineered Landfills: Daily, Intermediate, and Final California Cover Soils. J. Environ. Qual., 40: 1010-1020.

5. Darban Astane, A.R.; Hajilo, M., 2017. Factors Affecting the Rural Domestic Waste Generation. Global J. Environ. Sci. Manage., 3(4): 417-426.

6. Delkash, M., Zhou, B., Fotini, Ch., Rell, W., Imnof, M; 2016. Short-term landfill methane emissions dependency on wind, Waste Management, Volume 55; 288-298.

7. EPA, 2001. Methane Generation from Victorian Landfills. Publ.755. Epa. Info. Bull., EPA Victoria, 1-3.

8. GIZ, 2015. Landfills in Kosovo-Landfill Gas Prognosis and Roughly Cost Estimation of Gas Utilization. SEF-Energietechnik GmbH and GIZ. 1-43.

9. Huseyin, K.O; Mehmet, B.; Naim, S.; Semih, N,; Goksel, D., 2018. Determination of Seasonal Variations of Major Landfill Gas in Istanbul Kemerburgaz-Odayeri Solid Waste Landfill. Fresenius Environ. Bull., 272-276.

10. IPCC, 2007. Fourth Assessment Report: Climate Change 2007 (AR4). Intergovernmental Panel on Climate Change, Geneva, 1-112.

11. IPCC, 2006. Guidelines for National Greenhouse Gas Inventories. National Greenhouse Gas Inventories Program 2006, IPCC., 5: 1-40.

12. Kalantarifard, A., Yang, G.S. 2012. Estimation of Methane Production by LANDGEM Simulation Model from Tanjung Langsat Municipal Solid Waste Land-fill, Malaysia. International Journal of Science and Technology, 1, 481-487.

13. KAS, 2017. Municipal Waste Survey 2016. Kosovo Agency of Statistics, 1-15.

14. KEPA, 2015. Emissions of Green House Gas in Kosovo 2008-2013. Kosovo Environmental Protection Agency, 1-29.

15. KHMI,2017.MeteorologicalDataforKosovo,20012017. Kosovo Hidrometorological Institute., 1-14.

16. Kumar, S., Mondal, A,N.; Gaikwad, S.A.; Devotta, S.; Singh, R.N, 2004. Qualitative Assessment of Methane Emission Inventory from Municipal Solid Waste Disposal Sites: A Case Study. Atmos. Environ., 38: 4921-4929.

17. Kumar, A., Sharma, M.P. 2014. Estimation of GHG Emission and Energy Recovery Potential from MSW Landfill Sites. Sustainable Energy Technologies and Assessments, 5, 50-61.

18. MESP, 2017. Municipal Solid Waste Survey in Kosovo Municipalities. Ministry of Environment and Spatial Planning, 1-88.

19. Milenkovic, M.; Jakovlevic J.; Vlaskovic, V.; Mi- jacic, D., 2017. Environmental Protection and Economic Development in Kosovo. Institute for Territorial Economic Development. 1-50.

20. MLGA, 2017. Municipality Performances Report. Ministry of Local Government Administration, 1-140.

21. Morina, I.; Bajraktari, N.; Morina, R.; Shala, Sh.; Veselaj, T., 2017. Illegal Landfills in Sixteen Municipalities of Kosovo. Int. J. Environ. Sci., 48-53.

22. Mutasem, E.F.; Findikakis, A.N; Leckie, J.O., 2002. Environmental Impacts of Solid Waste Landfilling. Department of Civil Engineering, Stanford University, Stanford, California, U.S.A. J. Environ. Manage, 50: 1-25.

23. Powell, J.T.; Townsend, T.G.; Zimmerman, J.B., 2015. Estimation of Solid Waste Disposal Rates and Reduction Targets for Landfill Gas Emissions. Nat. Clim. Change Adv. Online Pub., 162-165.

24. Rodrigue, K., Essi, K., Cyril, K., Albert, T. 2018. Estimation of Methane Emission from Kossihouen Sanitary Landfill and Its Electricity Generation Potential (Côte d'Ivoire). Journal of Power and Energy Engineering, 6, 22-31.

25. Sadeghi, S., Shahmoradi, B., Maleki, A. 2015. Estimating Methane Gas Generation Rate from Sanandaj City Landfill Using LANDGEM Software. Research Journal of Environmental Sciences, 9, 280.

26. Sandhya, B.; Xaysackda V., 2011. Greenhouse Gas Emissions from Municipal Solid Waste Management in Vientiane, Lao PDR; Waste Manage. Res., 34(1): $30-37$.

27. Scheutz, C.K.; Bogner, J.E.; De Visscher, A.; Gebert, J.; Hilger, H.A; Spokas, K., 2009. Microbial Methane Oxidation Processes and Technologies for Mitigation of Landfill Gas Emissions. Waste Manage. Res., 27: 409-455.

28. UNDP, 2012. Kosovo Greenhouse Gas Emissions 2008 - 2009. UNDP Kosovo., 1-16.

29. Veselaj, T.; Hyseni, M.; Berisha, A.; Behrami, S.; Balaj, I.; Tahiri; F.; Makolli, V.; Pllana, A.; Gashi, P., 2014. State of the Waste and Chemicals, 2014 Report, Kosovo Environmental Protection Agency. 1-68.

30. Veselaj, T.; Hyseni, M.; Berisha, A.; Gashi, P., Morina, R.; Morina, I.; Cornel, F.G., 2013. Environmental Threatened Places - "Hotspots" in Kosovo. Int. Soc. for Environ. Epidemiol. (ISEE), Environment and Health Conference, Basel Switzerland.

31. Yang, L.; Chen, Z.; Zhang, X.; Liu, Y.; Xie, Y., 2015. Comparison Study of Landfill Gas Emissions from Subtropical Landfill with Various Phases: A Case Study in Wuhan, China. J. Air Waste Manage. Assoc. 65(8): 980-986.

32. Zawieja, I.; Wolski, P.; Wolny, L., 2011. Recovering of Biogas from Waste Deposited on Landfills. Ecol. Chem. and Engine. 18 (17): 923-932.

33. ZoiNet, 2012. West Balkan Environmental Core Set ofIndicators 2012.ZoiEnvironmentNetworkinCorporation with European Environment Agency, 1-44. 